\title{
Jomant Classifieds
}

ASSISTANT, ASSOCIATE, AND FULL-TIME FACULTY POSITIONS THE DEPARTMENT OF MATERIALS SCIENCE AND ENGINEERING (MSE) AT THE HERBERT WERTHEIM COLLEGE OF ENGINEERING AND THE UNIVERSITY OF FLORIDA

The Department of Materials Science and Engineering (MSE) at the Herbert Wertheim College of Engineering and the University of Florida is undergoing a major and ambitious expansion with the recent appointment of Dr. Michele Manuel as Department Chair. (http:// www.mse.ufl.edu/dr-michele-v-manuel-announcedas-department-chair-of-materials-science-andengineering/). Hiring of several new faculty members is planned. This includes the possibility of "cluster hires" of a group of connected applicants. The department invites applications for tenured or tenuretrack positions at the rank of Assistant, Associate or Full Professor. Of particular interest are candidates with expertise in the broad area of characterization of materials and phenomena using advanced analytical transition electron microscopy (TEM), development of new transmission electron microscopy techniques for materials characterization, and in-situ characterization of novel processes using electron microscopy. Applications are encouraged from individuals working on a broad range of materials related problems, including but not limited to:

- Metals

- Ceramics

- Polymers and Biomolecular Materials

- Electronic Materials

- Nuclear Materials

- Advanced Functional Materials

A doctoral degree in materials science and engineering or a related field is required, and postdoctoral experience is preferred.

The Department of MSE in the Herbert Wertheim College of Engineering at the University of Florida is a vibrant, multidisciplinary highly-collaborative environment, consistently ranked among the top departments for both graduate and undergraduate programs. This department is among the largest MSE departments in the nation with 26 faculty members, 290 graduate students, 213 undergraduates and over $\$ 9$ million in annual research expenditures. Research is central to the success of the program; and new faculty will be expected to initiate and sustain strong sponsored research and graduate training programs. With the appointment of our new chair, and full support from our dean, we plan a focused effort to become an exceptional department in terms of quality education, research and service to our state, country and world.

The department currently provides an integrated MSE education addressing biomaterials, ceramics, composites, electronic and optical materials, metals, and polymers. We anticipate that the successful applicant will continue the tradition of both developing and teaching courses at the undergraduate and graduate level and will assist in moving the department forward.

The search will receive applications until the positions are filled. The committee will begin reviewing applications August 31, 2017. To receive full consideration applicants must apply via UF Jobs at https://jobs.ufl.edu/ reference position number 00032577. You may email your electronic application package (PDF) that includes a cover letter with the rank being applied to, curriculum vitae, statement of research interests, statement of teaching interests and philosophy, and the contact information for three references to Ms. Venice Walker (venice @ mse.ufl.edu); however, this is not considered as having officially applied for the position. Candidates must apply at https://jobs.ufl.edu.

\section{I'VE SPECIALIZED FOR 36 YEARS}

in the placement of Metallurgical, Materials, and Welding Engineers in the areas of R\&D, Q.C. Production, Sales \& Marketing, nationwide. My background as a Met. Eng. can help you!

Salaries to \$190K. Fees paid by Company.

Michael Heineman, Meta-Find, Inc.

Phone: (212) 867-8100; E-mail: mikeh@meta-findny.com; Web: www.meta-findny.com 